\title{
Chitinimonas koreensis sp. nov., isolated from greenhouse soil in Korea
}

\author{
Byung-Yong Kim, ${ }^{1}$ Hang-Yeon Weon, ${ }^{2}$ Seung-Hee Yoo, ${ }^{1}$ \\ Wen-Ming Chen, ${ }^{3}$ Soon-Wo Kwon, ${ }^{1}$ Seung-Joo Go ${ }^{1}$ \\ and Erko Stackebrandt ${ }^{4}$
}

Correspondence

Soon-Wo Kwon

swkwon@rda.go.kr

\begin{abstract}
1,2Korean Agricultural Culture Collection (KACC), Microbial Genetics Division, National Institute of Agricultural Biotechnology ${ }^{1}$ and Applied Microbiology Division, National Institute of Agricultural Science and Technology2, Rural Development Administration, Suwon, Republic of Korea

${ }^{3}$ Department of Seafood Science, National Kaohsiung Marine University, Kaohsiung, Taiwan

${ }^{4}$ Deutsche Sammlung von Mikroorganismen und Zellkulturen $\mathrm{GmbH}$, Mascheroder Weg $1 \mathrm{~b}$, D-38124 Braunschweig, Germany
\end{abstract}

\begin{abstract}
Strain R2A43-10 $0^{\top}$ was isolated from a greenhouse soil in Korea. Cells were Gram-negative rods, motile by means of a single flagellum. Growth occurred at $10-40^{\circ} \mathrm{C}$ and at $\mathrm{pH} 5-8$. Ubiquinone-8 (Q-8) was the only respiratory lipoquinone. Major fatty acids were summed feature $3\left(C_{16: 1} \omega 7 c\right.$ and/or iso- $\left.C_{15: 0} 2-O H\right)$ and $C_{16: 0} .16 S$ rRNA gene sequence analysis revealed that strain $\mathrm{R} 2 \mathrm{~A} 43-10^{\top}$ was closely related to Chitinimonas taiwanensis $\mathrm{cf}^{\top}$ (sequence similarity of $94 \cdot 8 \%$ ), but it exhibited low sequence similarities ( $<92 \%)$ to other members of the Betaproteobacteria. The $\mathrm{G}+\mathrm{C}$ content of the genomic DNA of strain R2A43-10 ${ }^{\top}$ was $65.0 \mathrm{~mol} \%$. The novel isolate could be differentiated from C. taiwanensis $\mathrm{cf}^{\top}$ by several physiological properties. On the basis of genomic and phenotypic data, it is concluded that R2A43-10 $0^{\top}\left(=\right.$ KACC $11467^{\top}=$ DSM $\left.17726^{\top}\right)$ is the type strain of a novel species of the genus Chitinimonas, for which the name Chitinimonas koreensis sp. nov. is proposed.
\end{abstract}

The genus Chitinimonas (Chang et al., 2004) was classified as a distinct subline within the Betaproteobacteria, showing a distant relatedness to members of the genera Propionivibrio, Burkholderia, Pandoraea and others. At the time of writing, the genus comprised only one species, Chitinimonas taiwanensis, which was characterized as a Gram-negative, flagellated, chitinolytic, rod-shaped bacterium.

A single strain, designated R2A43-10 ${ }^{\mathrm{T}}$, was isolated from greenhouse soil in Korea. The strain was purified by streaking the soil sample on R2A medium (Reasoner \& Geldreich, 1985). The morphological, physiological and biochemical characteristics of strain $\mathrm{R} 2 \mathrm{~A} 43-10^{\mathrm{T}}$ were investigated using routine cultivation on R2A medium at $28^{\circ} \mathrm{C}$. Cell morphology was examined by light microscopy (AXIO; Zeiss) and transmission electron microscopy. Chitinolytic activity was characterized by using the method of Chang et al. (2004). Gram staining, catalase and oxidase activities, production of poly- $\beta$-hydroxybutyrate and hydrolysis of agar, casein, DNA, gelatin and starch were determined as described by Smibert \& Krieg

The GenBank/EMBL/DDBJ accession number for the 16S rRNA gene sequence of strain R2A43-10 ${ }^{\top}$ is DQ256728.

An HPLC profile of chitin-digested products of strain R2A43-10 ${ }^{\top}$ is available as a supplementary figure in IJSEM Online.
(1994). Growth was assessed at 5, 10, 20, 25, 30, 37, 40 and $45^{\circ} \mathrm{C}$, at $\mathrm{pH} 4,5,6,7,8,9$ and 10 and at $0,1,3,5$ and $7 \% \mathrm{NaCl}$. Hydrolysis of carboxymethylcellulose (Sigma) $(0 \cdot 1 \%)$ and tyrosine $(0.5 \%, \mathrm{w} / \mathrm{v})$ was also tested. The strain was additionally characterized by using the whole test spectrum of the API 20NE, API ID 32 GN and API ZYM systems (bioMérieux) according to the manufacturer's instructions.

Cells were harvested after $24 \mathrm{~h}$ growth on R2A medium and the identification of fatty acids was performed by use of the standard protocol of the Microbial Identification System (MIDI; Microbial ID). Isoprenoid quinones were analysed by HPLC as described by Groth et al. (1996). The DNA $\mathrm{G}+\mathrm{C}$ content was determined by using an HPLC-based method as described by Mesbah et al. (1989).

The 16S rRNA gene sequence of strain R2A43-10 ${ }^{\mathrm{T}}$ was analysed as described by Kwon et al. (2003). The sequence was aligned together with those of representative members of selected genera by using the CLUSTAL W program (Thompson et al., 1994). A phylogenetic analysis was performed using the software package MEGA (Molecular Evolutionary Genetics Analysis) version 3.1 (Kumar et al., 2004). Distances (using distance options according to the Kimura two-parameter model) and clustering using the 


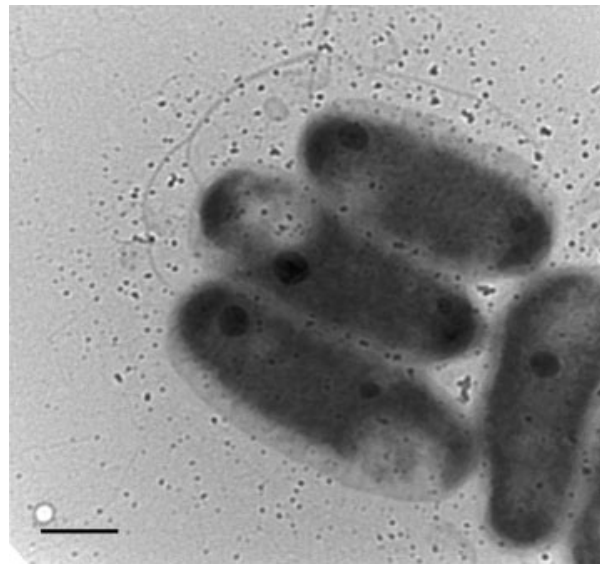

Fig. 1. Transmission electron micrograph of cells of strain R2A43-10 ${ }^{\top}$, each with a single flagellum. Bar, $500 \mathrm{~nm}$.

neighbour-joining and maximum-parsimony (Kumar et al., 2004) methods were determined by using bootstrap values based on 1000 replicates.

Colonies of strain R2A43-10 ${ }^{\mathrm{T}}$ were irregular and milky coloured on R2A medium. The strain grew well on chitin basal medium (Chang et al., 2004), R2A and nutrient agar (NA; Difco), but did not grow on trypticase soy agar (TSA; Difco) or MacConkey agar (Difco). Cells were Gramnegative, rod-shaped $(0 \cdot 7-0 \cdot 8$ by $1 \cdot 6-3 \cdot 8 \mu \mathrm{m})$ and motile by means of a single polar flagellum (Fig. 1).

Phylogenetic analysis of the 16S rRNA gene sequence of strain R2A43-10 ${ }^{\mathrm{T}}$ (Fig. 2) revealed that it was related most closely to C. taiwanensis $\mathrm{cf}^{\mathrm{T}}(94 \cdot 8 \%$ sequence similarity). Sequence similarities were below $92 \%$ to the type strains of other members of the Betaproteobacteria. The neighbourjoining (Fig. 2) and maximum-parsimony methods placed strains R2A43-10 ${ }^{\mathrm{T}}$ and C. taiwanensis $\mathrm{cf}^{\mathrm{T}}$ as phylogenetic neighbours within the Betaproteobacteria. The branching pattern was strongly supported by bootstrap analysis. This result was supported by other trees which included additional type strains of a diverse range of genera of the Betaproteobacteria (data not shown).

Analysis of the respiratory quinones of strain R2A43-10 ${ }^{\mathrm{T}}$ gave only one characteristic peak, corresponding to ubiquinone Q-8. Cellular fatty acid analysis revealed that summed feature $3\left(\mathrm{C}_{16: 1} \omega 7 c\right.$ and/or iso- $\left.\mathrm{C}_{15: 0} 2-\mathrm{OH}\right)$ was the most abundant component $(39 \cdot 5 \%)$, followed by $\mathrm{C}_{16: 0}$ $(33 \cdot 8 \%)$ and $\mathrm{C}_{18: 1} \omega 7 c(4 \cdot 6 \%)$. The fatty acid profile of $\mathrm{R} 2 \mathrm{~A} 43-10^{\mathrm{T}}$ was similar to that of $C$. taiwanensis $\mathrm{cf}^{\mathrm{T}}$ except that the latter strain contained $\mathrm{C}_{12: 0}(3 \cdot 7 \%$; absent from strain R2A43-10 ${ }^{\mathrm{T}}$ ) while strain R2A43-10 ${ }^{\mathrm{T}}$ contained $\mathrm{C}_{16: 0}$ 2-OH (3.0\%; absent from C. taiwanensis $\left.\mathrm{cf}^{\mathrm{T}}\right)$ (Table 1$)$. The $\mathrm{G}+\mathrm{C}$ content of its DNA was $65 \cdot 0 \mathrm{~mol} \%$.

The physiological and biochemical characteristics of strain R2A43-10 ${ }^{\mathrm{T}}$ and C. taiwanensis $\mathrm{cf}^{\mathrm{T}}$ are compared in Table 1. Strain R2A43-10 ${ }^{\mathrm{T}}$ differs clearly from C. taiwanensis $\mathrm{cf}^{\mathrm{T}}$ on the basis of a positive reaction for gelatin hydrolysis, negative reactions for urea and aesculin hydrolysis, and the presence of $\mathrm{C}_{16: 0} 2-\mathrm{OH}$ in the fatty acid profile. In the chitinolytic activity test, $C$. taiwanensis $\mathrm{cf}^{\mathrm{T}}$ produced chitotriose $\left[(\mathrm{GlcNAc})_{3}\right]$ as the major product of chitin cleavage. Isolate R2A $43-10^{\mathrm{T}}$, by contrast, produced mono$(\mathrm{GlcNAc})$ and disaccharides $\left[(\mathrm{GlcNAc})_{2}\right]$ as the major products and only a small amount of chitotriose (see Supplementary Fig. S1 in IJSEM Online).

On the basis of the polyphasic data presented, strain R2A43$10^{\mathrm{T}}$ is considered to represent a novel species of the genus Chitinimonas, for which the name Chitinimonas koreensis sp. nov. is proposed.

\section{Emended description of the genus Chitinimonas Chang et al. 2004}

The description of the genus Chitinimonas is as given by Chang et al. (2004) except that members of the genus are negative for indole production and glucose fermenta tion and may or may not hydrolyse aesculin, gelatin and urea.

\section{Description of Chitinimonas koreensis sp. nov.}

Chitinimonas koreensis (ko.re.en'sis. N.L. fem. adj. koreensis of Korea, where the type strain was isolated).

Cells are Gram-negative rods, motile by a single flagellum. Colonies are irregular, and no diffusible pigments are produced. Growth occurs at $10-40{ }^{\circ} \mathrm{C}, 0-1 \% \mathrm{NaCl}$ and pH 5-8. Poly- $\beta$-hydroxybutyrate is produced. Positive for catalase and oxidase, and hydrolysis of casein, chitin, gelatin, tyrosine and starch. Negative for hydrolysis of DNA, carboxymethylcellulose and urea. Other phenotypic properties are listed in Table 1. Ubiquinone- $8(\mathrm{Q}-8)$ is the only respiratory lipoquinone. Major fatty acids are summed

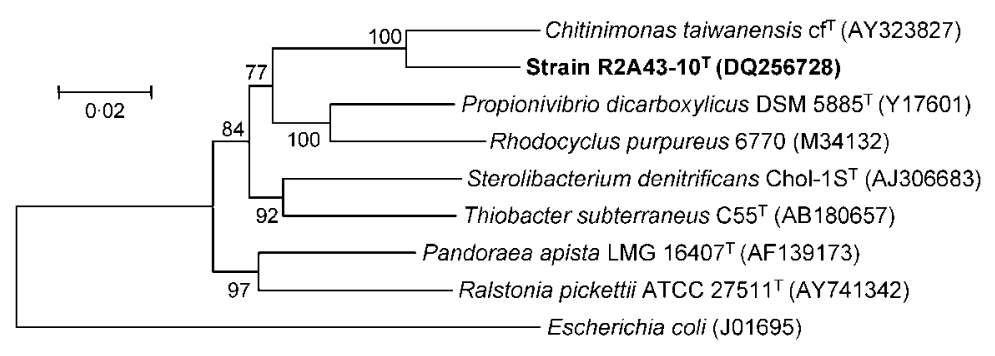

Fig. 2. Neighbour-joining phylogenetic tree based on 16S rRNA gene sequences (Escherichia coli positions 50-1483) of strain R2A43-10 $0^{\top}$ and its closest relatives. A sequence from $E$. coli (strain unknown) was used as the outgroup to root the tree. Numbers at nodes indicate levels of bootstrap support based on a neighbour-joining analysis of 1000 resampled datasets. Bar, 2 substitutions per $100 \mathrm{nt}$. 


\section{Table 1. Phenotypic comparison between strain $R 2 A 43-10^{\top}$ and C. taiwanensis $\mathrm{cf}^{\top}$}

Data for C. taiwanensis $\mathrm{cf}^{\mathrm{T}}$ were taken from Chang et al. (2004). According to API 20NE and API ZYM test strips, both strains are positive for nitrate reduction, esterase (C4), esterase lipase (C8), leucine arylamidase, acid phosphatase, naphthol-AS-BI-phosphohydrolase and $\alpha$-galactosidase and negative for indole production, glucose fermentation, arginine dihydrolase, $\beta$-glucuronidase, $\alpha$-glucosidase, $\beta$-glucosidase, $\alpha$-mannosidase and $\alpha$-fucosidase. According to API $20 \mathrm{NE}$ and API ID 32 GN test strips, both strains are positive for D-glucose, D-maltose, glycogen, valeric acid, 3-hydroxybutyric acid and L-proline and negative for assimilation of L-arabinose, potassium gluconate, capric acid, adipic acid, trisodium citrate, phenylacetic acid, L-rhamnose, D-ribose, inositol, itaconic acid, suberic acid, sodium malonate, sodium acetate, L-alanine, potassium 5-ketogluconate, 3-hydroxybenzoic acid, salicin, D-melibiose, L-fucose, propionic acid, potassium 2-ketogluconate and 4-hydroxybenzoic acid. +, Positive; - , negative; ND, not detected.

\begin{tabular}{|c|c|c|}
\hline Characteristic & $\mathrm{R} 2 \mathrm{~A} 43-10^{\mathrm{T}}$ & C. taiwanensis $\mathrm{cf}^{\mathrm{T}}$ \\
\hline Major products of chitin cleavage & GlcNAc, $(\mathrm{GlcNAc})_{2}$ & $(\mathrm{GlcNAc})_{3}$ \\
\hline \multicolumn{3}{|l|}{ API $20 \mathrm{NE}$ and API ZYM strip results } \\
\hline Urease & - & + \\
\hline Aesculin hydrolysis & - & + \\
\hline Gelatin hydrolysis & + & - \\
\hline$\beta$-Galactosidase & - & + \\
\hline Alkaline phosphatase & + & - \\
\hline Lipase $(\mathrm{C} 14)$ & - & + \\
\hline$\beta$-Galactosidase & - & + \\
\hline Alkaline phosphatase & + & - \\
\hline Valine arylamidase & - & + \\
\hline Cystine arylamidase & - & + \\
\hline Trypsin & - & + \\
\hline$\alpha$-Chymotrypsin & - & + \\
\hline$N$-Acetyl- $\beta$-glucosaminidase & - & + \\
\hline \multicolumn{3}{|c|}{ Assimilation according to API $20 \mathrm{NE}$ and API ID32 GN strips } \\
\hline D-Mannose & + & - \\
\hline D-Mannitol & - & + \\
\hline$N$-Acetylglucosamine & - & + \\
\hline Malic acid & + & - \\
\hline Sucrose & + & - \\
\hline Lactic acid & - & + \\
\hline L-Serine & + & - \\
\hline D-Sorbitol & - & + \\
\hline L-Histidine & + & - \\
\hline \multicolumn{3}{|l|}{ Fatty acids $(\% \text { of total })^{\star}$} \\
\hline $\mathrm{C}_{12: 0}$ & ND & $3 \cdot 7$ \\
\hline $\mathrm{C}_{12: 0} 2-\mathrm{OH}$ & $3 \cdot 3$ & $1 \cdot 8$ \\
\hline $\mathrm{C}_{14: 0}$ & $1 \cdot 7$ & $1 \cdot 3$ \\
\hline $\mathrm{C}_{16: 0}$ & $33 \cdot 8$ & $29 \cdot 2$ \\
\hline $\mathrm{C}_{16: 0} 2-\mathrm{OH}$ & $3 \cdot 0$ & $\mathrm{ND}$ \\
\hline $\mathrm{C}_{16: 1} \omega 5 c$ & ND & $0 \cdot 6$ \\
\hline $\mathrm{C}_{18: 1} \omega 7 c$ & $4 \cdot 6$ & $11 \cdot 6$ \\
\hline $\mathrm{C}_{18: 0}$ & $1 \cdot 9$ & $0 \cdot 6$ \\
\hline Summed feature $3 \dagger$ & $39 \cdot 5$ & $49 \cdot 4$ \\
\hline DNA G $+C$ content $(\mathrm{mol} \%)$ & $65 \cdot 0$ & $62 \cdot 8$ \\
\hline
\end{tabular}

${ }^{*}$ Fatty acids that account for $<0.5 \%$ of the total are not shown. $\dagger$ Summed feature 3 consisted of $\mathrm{C}_{16: 1} \omega 7 c$ and/or iso- $\mathrm{C}_{15: 0} 2-\mathrm{OH}$. 
feature $3\left(\mathrm{C}_{16: 1} \omega 7 c\right.$ and/or iso- $\left.\mathrm{C}_{15: 0} 2-\mathrm{OH}\right)$ and $\mathrm{C}_{16: 0}$. The $\mathrm{G}+\mathrm{C}$ content of the genomic DNA is $65 \mathrm{~mol} \%$.

The type strain, R2A43-10 ${ }^{\mathrm{T}}\left(=\mathrm{KACC} 11467^{\mathrm{T}}=\mathrm{DSM}\right.$ $\left.17726^{\mathrm{T}}\right)$, was isolated from greenhouse soil cultivated with cucumber in Sangju Province, Korea.

\section{References}

Chang, S. C., Wang, J. T., Vandamme, P., Hwang, J. H., Chang, P. S. \& Chen, W. M. (2004). Chitinimonas taiwanensis gen. nov., sp. nov., a novel chitinolytic bacterium isolated from a freshwater pond for shrimp culture. Syst Appl Microbiol 27, 43-49.

Groth, I., Schumann, P., Weiss, N., Martin, K. \& Rainey, F. A. (1996). Agrococcus jenensis gen. nov., sp. nov., a new genus of actinomycetes with diaminobutyric acid in the cell wall. Int J Syst Bacteriol 46, 234-239.

Kumar, S., Tamura, K. \& Nei, M. (2004). MEGA3: integrated software for molecular evolutionary genetics analysis and sequence alignment. Brief Bioinform 5, 150-163.
Kwon, S. W., Kim, J. S., Park, I. C., Yoon, S. H., Park, D. H., Lim, C. K \& Go, S. J. (2003). Pseudomonas koreensis sp. nov., Pseudomonas umsongensis sp. nov. and Pseudomonas jinjuensis sp. nov., novel species from farm soils in Korea. Int J Syst Evol Microbiol 53, 21-27.

Mesbah, M., Premachandran, U. \& Whitman, W. B. (1989). Precise measurement of the $\mathrm{G}+\mathrm{C}$ content of deoxyribonucleic acid by high-performance liquid chromatography. Int J Syst Bacteriol 39, 159-167.

Reasoner, D. J. \& Geldreich, E. E. (1985). A new medium for the enumeration and subculture of bacteria from potable water. Appl Environ Microbiol 49, 1-7.

Smibert, R. M. \& Krieg, N. R. (1994). Phenotypic characterization. In Methods for General and Molecular Bacteriology, pp. 607-654. Edited by P. Gerhardt, R. G. E. Murray, W. A. Wood \& N. R. Krieg. Washington, DC: American Society for Microbiology.

Thompson, J. D., Higgins, D. G. \& Gibson, T. J. (1994). CLUSTAL W: improving the sensitivity of progressive multiple sequence alignment through sequence weighting, position-specific gap penalties and weight matrix choice. Nucleic Acids Res 22, 4673-4680. 